\title{
Electric Load Influence on Performances of a Composite Plant for Hydrogen Production from RES and its Conversion in Electricity
}

\author{
Rosario Carbone ${ }^{1}$, Concettina Marino ${ }^{2, *(0)}$, Antonino Nucara ${ }^{2}\left(\mathbb{D}\right.$, Maria Francesca Panzera ${ }^{2}$ \\ and Matilde Pietrafesa ${ }^{2}$ \\ 1 Department of Information Engineering, Infrastructures and Sustainable Energy, \\ 89122 Reggio Calabria, Italy; rosario.carbone@unirc.it \\ 2 Department of Civil, Energetic, Environmental and Material Engineering, 89122 Reggio Calabria, Italy; \\ antonino.nucara@unirc.it (A.N.); francesca.panzera@unirc.it (M.F.P.); matilde.pietrafesa@unirc.it (M.P.) \\ * Correspondence: concettina.marino@unirc.it; Tel.: +39-0965-169-2411
}

Received: 9 October 2019; Accepted: 7 November 2019; Published: 13 November 2019

\begin{abstract}
The analysis here presented investigates the influence of electrical load on the operational performances of a plant for hydrogen production from solar energy and its conversion in electricity via a fuel cell. The plant is an actual one, currently under construction, in Reggio Calabria (Italy), at the site of the Mediterranean university campus; it is composed of a Renewable Energy Source (RES) section (photovoltaic panels), a hydrogen production section, and a fuel cell power section feeding the electrical energy demand of the load. Two different load configurations have been analysed and simulations have been carried out through Homer $^{\mathrm{TM}}$ simulation code. Results allow interesting conclusions regarding the plant operation to be drawn. The study could have a remarkable role in supporting further research activities aimed at the assessment of the optimal configuration of this type of pioneering plants, designed for feeding electrical loads, possibly, in a self-sufficient way.
\end{abstract}

Keywords: hydrogen production; photovoltaic systems; fuel cell; electrical load

\section{Introduction}

Conventional wisdom is that the stabilization of the atmospheric concentration of anthropogenic greenhouse gases (GHGs) will require decarbonization of most of the human activities during the next century [1]. This commitment may be fulfilled by means of various strategies and measures involving, in particular, the implementation of systems significantly powered by renewable energy sources, as discussed by many authors.

Among them, for example, Hvelplund [2] deals with an analysis of the Dane energy market, suggesting a technical integration between all the renewable sources involved in the national system; Lund [3] presents this issue from a social and political point of view, expressing all the limits of this transition towards renewable sources, while Foley and Olabi [4] focus on the environmental consequences and influences of a system based on renewable energy on global climate changes. Also, Narayanan et al. [5] investigate the feasibility of having a local energy system fully based on renewable sources, considering also the presence of battery energy storage systems; Da Silva [6], instead, approaches the theme of Renewable Energy Source (RES) introducing a mathematical model to simulate the development of energy conversion technologies.

The use of renewable energy sources has been widely discussed also from the legislative point of view: in particular, the last European Directive [7] promotes the use of energy from renewable sources, including hydrogen as an energy vector. 
Other authors have focused their attention on the use of RES in specific sectors, such as photovoltaic (PV) production [8], smart grids [9,10], electric mobility [11,12], or storage systems [13].

Among the main sectors where RES can be implemented, the buildings sector is certainly one of the most relevant compartments on which taking actions is done, due to its share of global final energy consumption and global emissions [14].

In the United States, it accounted for about $41 \%$ of primary energy consumption in 2010 [14], whereas, in Europe, buildings are responsible for $40 \%$ of energy end use and $36 \%$ of $\mathrm{CO}_{2}$ emission $[7,15]$.

Therefore, improving the energy performance of the building stock, also through the introduction of distributed micro-generation-based systems of Renewable Energy Sources, has become one of the pivotal strategies with a view to both addressing energy supply global issues and limiting climate change. Within this framework, the concept of Nearly Zero-Energy Buildings (NZEB) [16-18] finds its rationale; but to reach the NZEB target, the implementation of RES at the building level is quite unavoidable [19].

As a matter of fact, despite the fact that electricity production from RES is usually recognized as randomly variable [20], depending on the site climate conditions, it can efficiently satisfy loads when supported by energy storage systems. These latter exploit different techniques, referring to a pumped hydropower storage, like the one proposed by Krajačić et al. [21], or a compressed-air energy storage in a pool, analysed by Foley and Lobera [22], or a thermal energy storage using phase-changing materials for industrial energy, implemented by López-Sabirón et al. [23]; though, currently, the most diffused devices are still batteries [24].

However, innovative systems are increasingly drawing the attention of researchers and technicians, and, in this context, hydrogen-based devices are recognized among the most environmentally sustainable methods to accumulate renewable energy.

Indeed, hydrogen can be produced in different ways, but water electrolysis, which is a process able to be fueled by RES, has been receiving increasing attention [25], even though several issues, especially regarding costs, transport, and distribution [26], are still to be effectively addressed.

Different studies on the topic are currently available. Among them, Saeedmanesh et al. [27] consider hydrogen, amid RES, as the only option with sufficient storage capacity, able to provide a seasonal storage at low cost; Camacho and Ruggeri [28] propose an energy sustainability analysis both at short and long term applied to the case study of hydrogen production at small scale; Carroquino et al. [29], instead, focus on an application of a hydrogen systems in the agricultural context.

Therefore, to sum up, hydrogen is nowadays considered as one of the most promising and sustainable energy careers [7]. Capable of supporting RES systems as a storage agent, it is emission-free and, theoretically, it can supply both long-term and short-term storage devices [30].

In addition, hydrogen-based systems, equipped with fuel cells, may be also independently fed by a hydrogen pipeline when it is available, so that energy production from RES can be also flanked by several energy supplying networks: power grids and hydrogen nets [31].

Several configurations of these types of systems are possible, depending on the ways with which the various components interact and the energy flows are allowed to distribute among the different apparatuses. This fact enhances the flexibility of the system operation and it is a valuable advantage for a distributed micro-generation scheme within smart grid structures, even though reliability issues and control strategies should be accurately taken into account [32,33].

In this framework, the analysis proposed in the paper collocates within the larger research frame regarding the procedures, patterns, and systems aimed at fully realizing the decarbonization process which is the goal of several actions worldwide planned by various governments [15].

As formerly suggested, Renewable Energy Sources (RES) play a pivotal role with a view to enhancing diversity and safety of energy supplies and curbing polluting emissions; but it is to be considered that, in order to optimally exploit the features of RES, characterized by a small capacity and randomly variable performances, energy systems based on distributed micro-generation, smart grids, and efficient storage devices should be designed and implemented. 
As a matter of fact, distributed micro-generation systems, also equipped with storage devices operating as energy buffers, can function either in grid-connected or stand-alone mode, thereby contributing to solving local energy issues and enhancing grid flexibility which is also one of the main requisites of smart energy networks.

The system analyzed in this paper collocates in this context. Currently under construction, in Reggio Calabria (Italy), at the site of the Mediterranean university campus, it is composed of a Renewable Energy Source section (PV panels), a hydrogen production section (electrolyser and control systems), and a power section (Proton Exchange Membranes cell) feeding the electrical energy demand of the load [34,35].

The general purpose of the whole planned research is the analysis of the system performances, also from an experimental point of view, in order to both verify the reliability of this type of apparatuses, at least in Mediterranean climate, and prove the existence of possible optimal configurations in view of self-sufficient arrangements, especially when domestic loads are involved.

The analysis presented in the paper collocates in this more general frame and regards the effect of the load configuration on the system operation, with the aim of preliminary assessing of the features of the energy demand, which is able to be efficiently met by the system, possibly with a minimal involvement of the power grid.

In detail, the analysis proposed in the paper investigates the influence of the load configurations on the plant operational efficiency. Two extreme load configurations, which vary only for the period of the load activation, have been considered: in the first pattern, load energy demand starts at sunset and lasts until dawn; on the contrary, in the second pattern, the load energy demand occurs in the presence of daylight only.

All the simulations have been performed by means of Homer $^{\mathrm{TM}}$ [36] simulation code.

Results have allowed interesting conclusions regarding the system operation to be drawn. They might constitute important information supporting research activities aimed at the assessment of the optimal configuration of this type of pioneering plants designed to feed loads, possibly in a self-sufficient way.

\section{Methodology}

The paper aims at the analysis of the influence of load configurations on the performances of a plant designed for production of hydrogen from solar energy and its successive conversion to electrical energy through a fuel cell.

The plant is an actual one which is under construction at the Mediterranean University campus site ( $38^{\circ} 07^{\prime} 12^{\prime \prime}$ North latitude, $15^{\circ} 40^{\prime} 12^{\prime \prime}$ East longitude). Its performances have been analyzed using Homer ${ }^{\mathrm{TM}}$ simulation code, with a view to configuring the electrical load and comparing results to the experimental data to be acquired in the next future.

Specifically, two load configurations have been simulated; they differ for the period of time during which the electrical energy demand occurs, but not for power. In other words, the same constant load was activated either during nighttime (case a) or during daylight (case b).

The rationale at the basis of this choice is to analyze the effect of two possible extreme configurations of the load: the first occurring during the presence of solar irradiance, whereas the second occurred during night, when no production of the PV system is involved.

Simulations have been performed with hourly time steps; they were set up so that the grid is involved only just in case the other energy sources, which the plant is composed of (PV generator, battery and fuel cell), do not suffice to meet the load.

Results of the simulations consisted of: photovoltaic energy production and its distribution among the various uses characterizing the system (load, electrolyser producing hydrogen, battery charge); shares of energy coming from the various sources (PV generator, battery, fuel cell) and delivered to the load; hydrogen production and amount of stored hydrogen. 
They allowed the analysis of the influence of load configurations on system performances, so that interesting conclusions on possible future plant patterns and operation have been able to be drawn, especially with regard to the features of the energy demand, which is able to be efficiently met by the system, possibly with a minimal involvement of the power grid.

This is to be considered as part of a broader research activity which is aimed at the analysis of the system performances, also from an experimental point of view, in order to both verify the reliability of these types of apparatuses, at least in the Mediterranean climate, and prove the existence of possible optimal configurations in view of self-sufficient arrangements.

\section{The Case-Study Plant}

Simulations regarded the Mediterranean University's actual plant (Figure 1), which is currently on the verge of being activated. Its features and the climate conditions of the site are reported in the following sections.

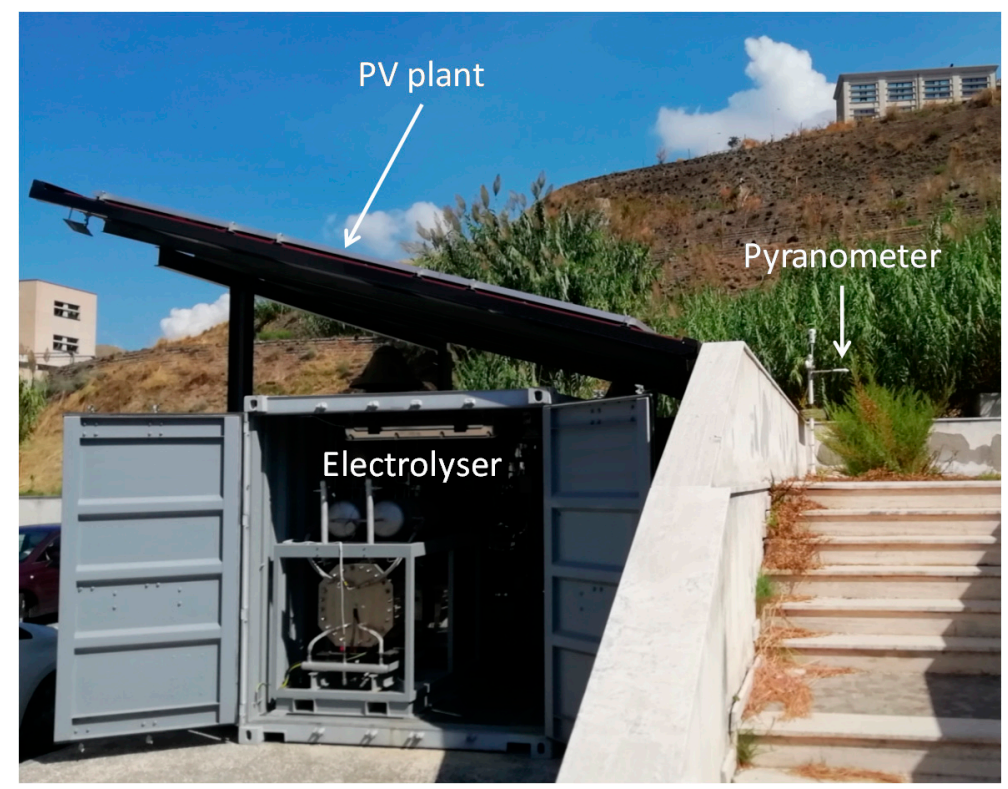

Figure 1. The Mediterranean University case-study plant.

\subsection{The Mediterranean University's Plant}

The plant's operational structure is inferable from Figure 2. It consists of a PV generator, a battery pack, an electrolyser, a hydrogen tank, and a fuel cell. Information regarding the economic sustainability of the system can be found in [8].

Actually, the whole set of energy conversion systems which constitute the plant (PV generator, battery, fuel cell) is able to feed the load, whose energy demand can be also satisfied by the grid, which in turn intervenes, only when needed, to supply the possibly lacking energy.

A unique DC/AC converter allows the load to be connected to both the set of energy conversion systems of the plant and to the grid.

The characteristics of every single device are reported in the following Tables 1-6.

The PV array is composed of 18 panels, for a global maximum power of $6.48 \mathrm{kWp}$.

As regards the battery pack, it must be underlined that Table 2 reports the features of one single element of the device, which is indeed composed of 8 elements (two strings of 4 elements). 


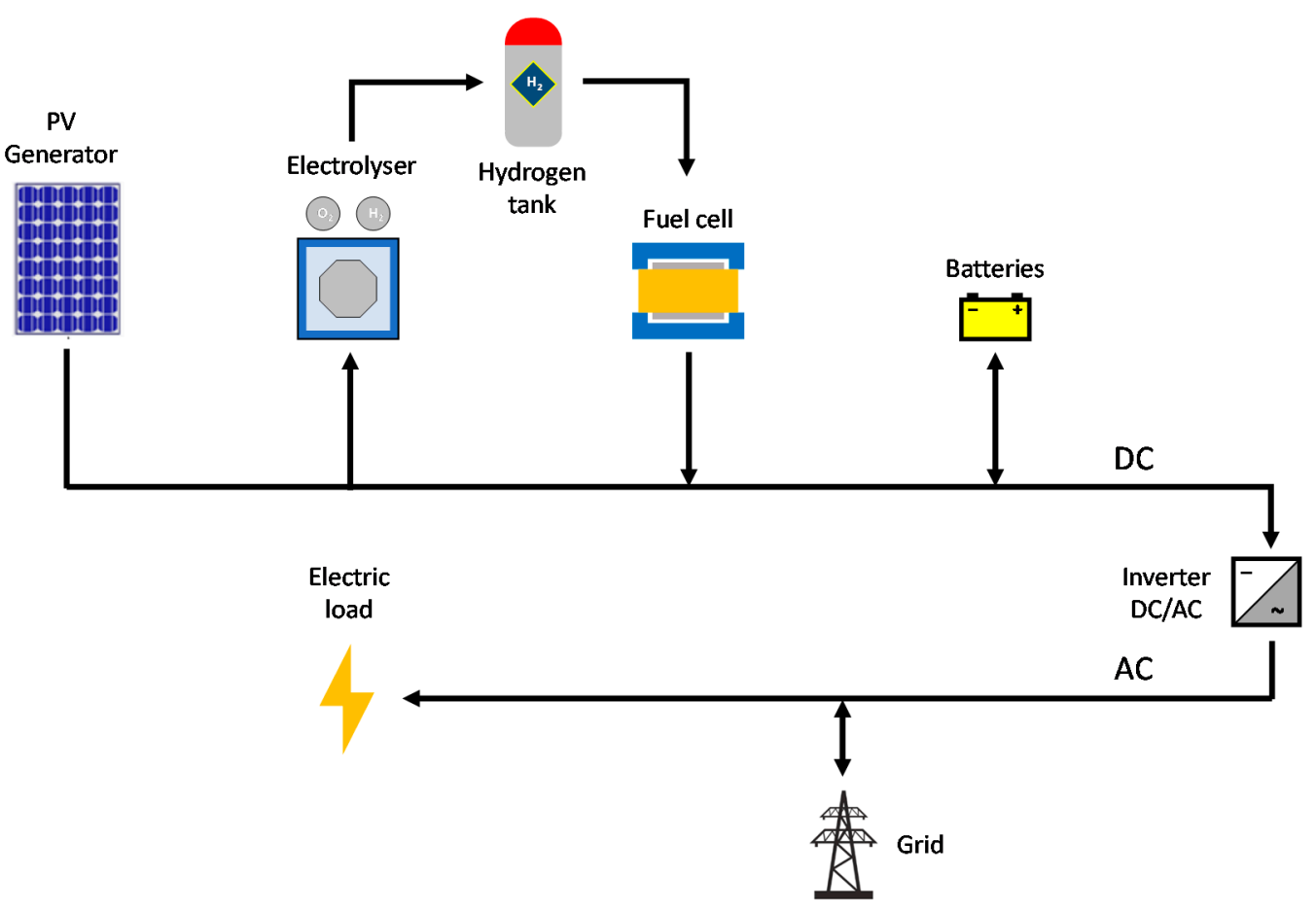

Figure 2. Scheme of the Mediterranean University Plant.

Table 1. Characteristics of PV panels.

\begin{tabular}{cc}
\hline Type of Panel & Monocrystalline Silicon \\
\hline Maximum power & $360 \mathrm{Wp}$ \\
\hline Efficiency $(\eta)$ & $22.1 \%$ \\
\hline Temperature coefficient $(\beta)$ & $-0.29 \% /{ }^{\circ} \mathrm{C}$ \\
\hline Nominal Operating Cell Temperature (NOCT) & $41.5^{\circ} \mathrm{C}$ \\
\hline
\end{tabular}

Table 2. Characteristics of the battery element composing the battery pack.

\begin{tabular}{cc}
\hline Nominal Capacity & $\mathbf{2 4} \mathbf{A h}$ \\
\hline Nominal Voltage & $12 \mathrm{~V}$ \\
\hline Round-trip efficiency & $80 \%$ \\
\hline Min. state of charge & $40 \%$ \\
\hline Max. charge rate & $1 \mathrm{~A} / \mathrm{Ah}$ \\
\hline
\end{tabular}

Table 3. Technical characteristics of the electrolyser.

\begin{tabular}{cccc}
\hline Stack Capacity & $\mathbf{2 ~ N m 3 / h}$ & Amount of Demineralized Water & $\mathbf{1 . 9} \mathbf{~} / \mathbf{h}$ \\
\hline Control interval & $25-100 \%$ & Fixed residue & $\operatorname{max~} 2 \mathrm{mg} / \mathrm{L}$ \\
\hline Electric power & $2-10 \mathrm{~kW}$ & Chloride content & Absent \\
\hline Conversion efficiency & $60 \%$ & Maximum conductivity $\left(25^{\circ} \mathrm{C}\right)$ & $5 \mu \mathrm{S} / \mathrm{cm}$ \\
\hline Operating pressure & $20 \mathrm{bar}$ & Purity of hydrogen exiting stack & $99.80 \%$ \\
\hline Operating temperature & $80{ }^{\circ} \mathrm{C}$ & Purity of stored hydrogen & $99.99 \%$ \\
\hline
\end{tabular}


Table 4. Characteristics of the inverter DC/AC.

\begin{tabular}{cccc}
\hline Nominal Power & $\mathbf{6 0 0 0 ~ V A}$ & $\begin{array}{c}\text { Max Power of } \\
\text { Charge/Discharge }\end{array}$ & $\mathbf{6 0 0 0 ~ W}$ \\
\hline DC input & $\begin{array}{c}720 \mathrm{VDC} \\
11 \mathrm{~A}\end{array}$ & Efficiency & $97.6 \%$ \\
\hline AC output & $\begin{array}{c}400 \mathrm{VAC} \\
50 \mathrm{~Hz} 9 \mathrm{~A}\end{array}$ & \\
\hline
\end{tabular}

Table 5. Characteristics of the fuel cell.

\begin{tabular}{cccc}
\hline Delivered Power & $\mathbf{1}^{\prime} \mathbf{6 7 6 ~ W}$ & Storing Temperature & $-\mathbf{3 0 - 4 0} \mathbf{~}^{\circ} \mathbf{C}$ \\
\hline Output voltage & $47 \div 57 \mathrm{Vdc}$ & Environment temperature & $-45-70{ }^{\circ} \mathrm{C}$ \\
\hline Maximum $\mathrm{H}_{2}$ consumption & $1.37 \mathrm{Nm}^{3} / \mathrm{h}$ & Cabinet temperature & $0-60{ }^{\circ} \mathrm{C}$ \\
\hline Efficiency & $40 \%$ & $\mathrm{H}_{2}$ pressure & $0.43 \mathrm{bar}$ \\
\hline Delivered power & $1^{\prime} 676 \mathrm{~W}$ & Storing temperature & $-30-40{ }^{\circ} \mathrm{C}$ \\
\hline \multirow{2}{*}{ Input current for auxiliaries } & $220 / 50$ & $\mathrm{H}_{2}$ purity & $99.95 \%$ \\
\hline
\end{tabular}

Table 6. Characteristics of the Hydrogen tank.

\begin{tabular}{cc}
\hline Pmax & 30 bar \\
\hline Volume & $0.75 \mathrm{~m}^{3}$ \\
\hline Capacity at $\mathrm{p}=20 \mathrm{bar}$ & $1.8 \mathrm{~kg}$ \\
\hline
\end{tabular}

As far as the system's operational scheme is concerned, it is worth noting that the system has no gas compression device and that the electrolyser produces hydrogen at a pressure of 20 bar (Table 3). When the pressure inside the tank reaches the value of $20 \mathrm{bar}$, the hydrogen production is halted.

At the pressure of $20 \mathrm{bar}$, a hydrogen mass of $1.8 \mathrm{~kg}$ is storable within the tank (Table 6). This is the capacity size of the tank and a control parameter for the simulation code (HOMER $\left.{ }^{\mathrm{TM}}\right)$, which stops the hydrogen production when the stored gas mass is equal to or higher than $1.8 \mathrm{~kg}$.

\subsection{Site Weather Features}

The formerly described plant is located at the site of the Mediterranean University campus $\left(38^{\circ} 07^{\prime} 12^{\prime \prime}\right.$ North latitude, $15^{\circ} 40^{\prime} 12^{\prime \prime}$ East longitude), in Reggio Calabria, a town situated on the Southern coast of the Italian Peninsula and characterized by a typical Mediterranean climate profile, with warm temperatures and dry warm summer [37].

The needed climate data were obtained through a measurement campaign performed at the university site in 2018.

Specifically, solar radiation was measured by means of a Kipp and Zonen CNR4 ${ }^{\mathrm{TM}}$ net radiometer, which, in turn, consists of a pyranometer pair, disposed on the opposite surfaces of the probe's plane, and a pyrgeometer pair in a similar configuration (Table 7).

Air temperature was measured by means of the Vaisala ${ }^{\mathrm{TM}}$ WXT 530 weather station (Table 8), disposed on the roof of one of the University's buildings.

Monthly values of the measured data are reported in Figure 3, whereas monthly average values of the hourly solar radiation on horizontal plane, for June and December, are reported in Figure 4. 
Table 7. Technical characteristics of CNR4TM net radiometer.

\begin{tabular}{cc}
\hline Spectral Range & 300-2800 $\mathbf{~ n m ~ ( 5 0 \% ~ p o i n t s ) ~}$ \\
\hline Sensitivity & 10 to $20 \mu \mathrm{V} /\left(\mathrm{W} / \mathrm{m}^{2}\right)$ \\
\hline Response time & $<18 \mathrm{~s}(95 \%$ response $)$ \\
\hline Non-linearity & $<1 \%$ (from 0 to $1000 \mathrm{~W} / \mathrm{m}^{2}$ irradiance) \\
\hline Tilt error & $<1 \%$ \\
\hline Field of view: & $180^{\circ}$ \\
\hline Directional error: & $<20 \mathrm{~W} / \mathrm{m}^{2}$ (angles up to $80^{\circ}$ with $1000 \mathrm{~W} / \mathrm{m}^{2}$ beam radiation $)$ \\
\hline Irradiance: & 0 to $2000 \mathrm{~W} / \mathrm{m}^{2}$ \\
\hline Uncertainty in daily total & $<5 \%(95 \%$ confidence level) \\
\hline
\end{tabular}

Table 8. Technical characteristics of Vaisala WXT520.

\begin{tabular}{ccc}
\hline Measured Parameter & Measurement Range & Accuracy \\
\hline Air temperature & $-52 \ldots+60{ }^{\circ} \mathrm{C}$ & $\pm 0.3{ }^{\circ} \mathrm{C}$ \\
\hline Relative Humidity $(\mathrm{RH})$ & $0-100 \%$ & $\pm 3 \% \mathrm{RH}$ \\
\hline Rain intensity & $0 \ldots 200 \mathrm{~mm} / \mathrm{h}$ & $\pm 0.1 \mathrm{~mm} / \mathrm{h}$ \\
\hline
\end{tabular}

$\square$ Solar radiation $\quad$ Air temperature

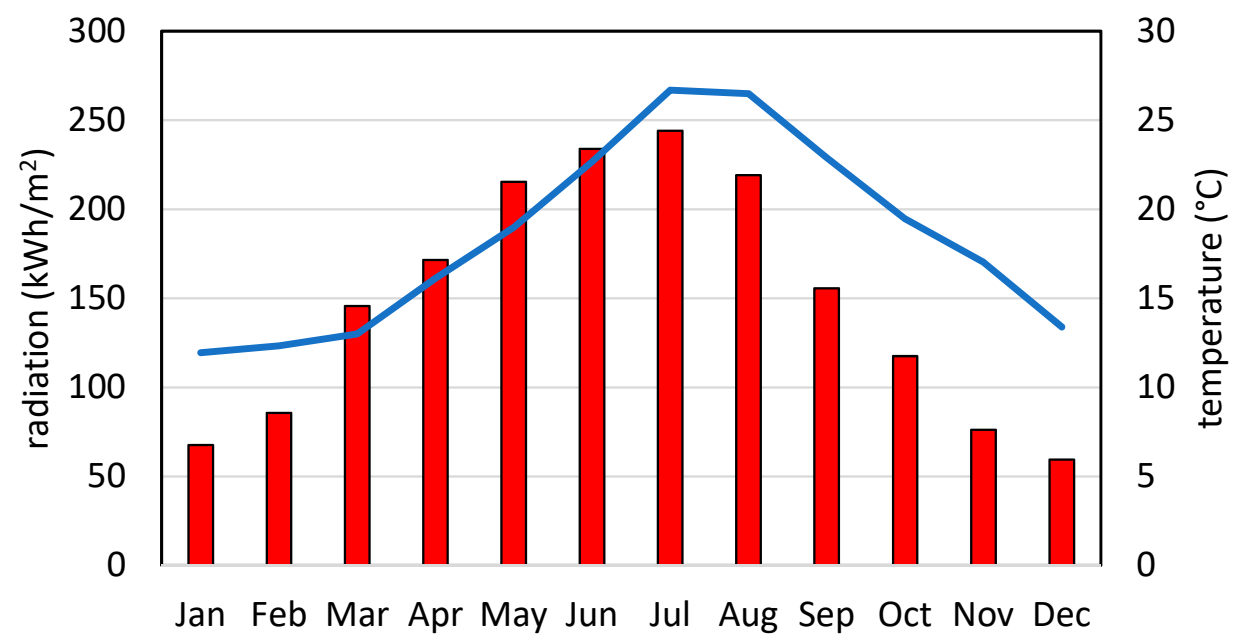

Figure 3. Climate data: Monthly global solar radiation on horizontal surface; monthly average air temperature.
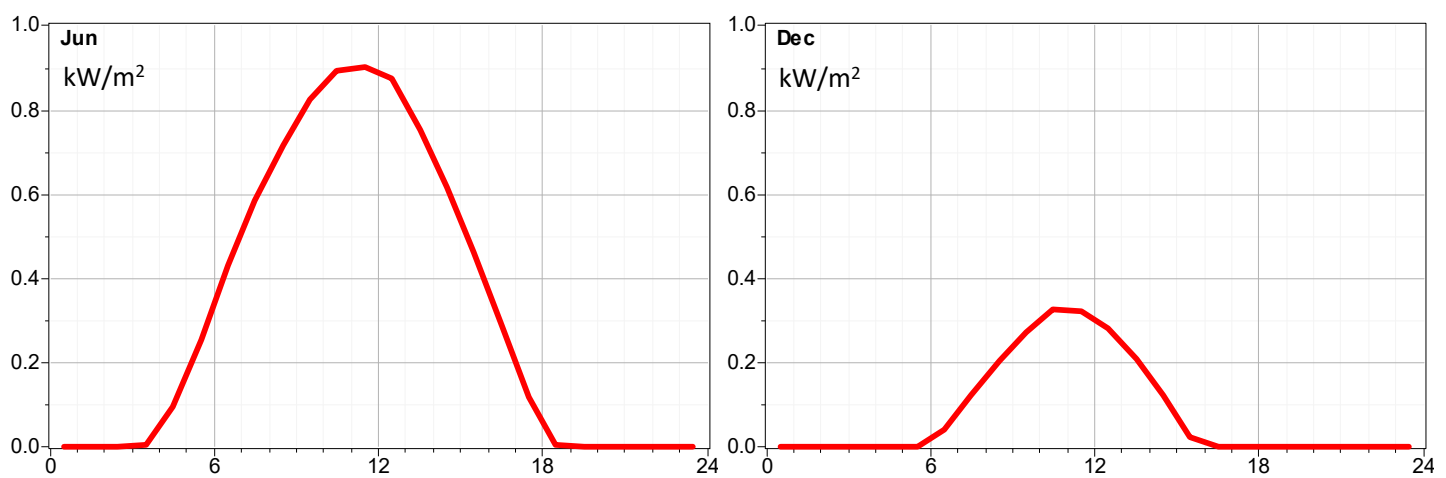

Figure 4. Monthly average hourly radiation on horizontal surface in June and December 2018. 


\subsection{Load Configurations}

In order to analyze the effect of two possible extreme configurations of the load, two different load configurations have been considered for simulations: they differ for the period of time during which the electrical energy demand occurs. Basically, the same constant load of $1.5 \mathrm{~kW}$ was activated either during nighttime (case a: Night Load) or during daytime (case b: Daylight Load). In other words, in the first pattern (Night Load), load energy demand starts at sunset and lasts until dawn; on the contrary, in the second pattern (Daylight Load), the load energy demand occurs in the presence of daylight only.

The monthly energy demand due to the load, for both considered configurations, is reported in Figure 5.

In spite of the fact that the load is constant, the monthly values of the energy demand differ because they depend on the extent of daylight period, which varies as a function of the time of the year and number of days which compose the month.

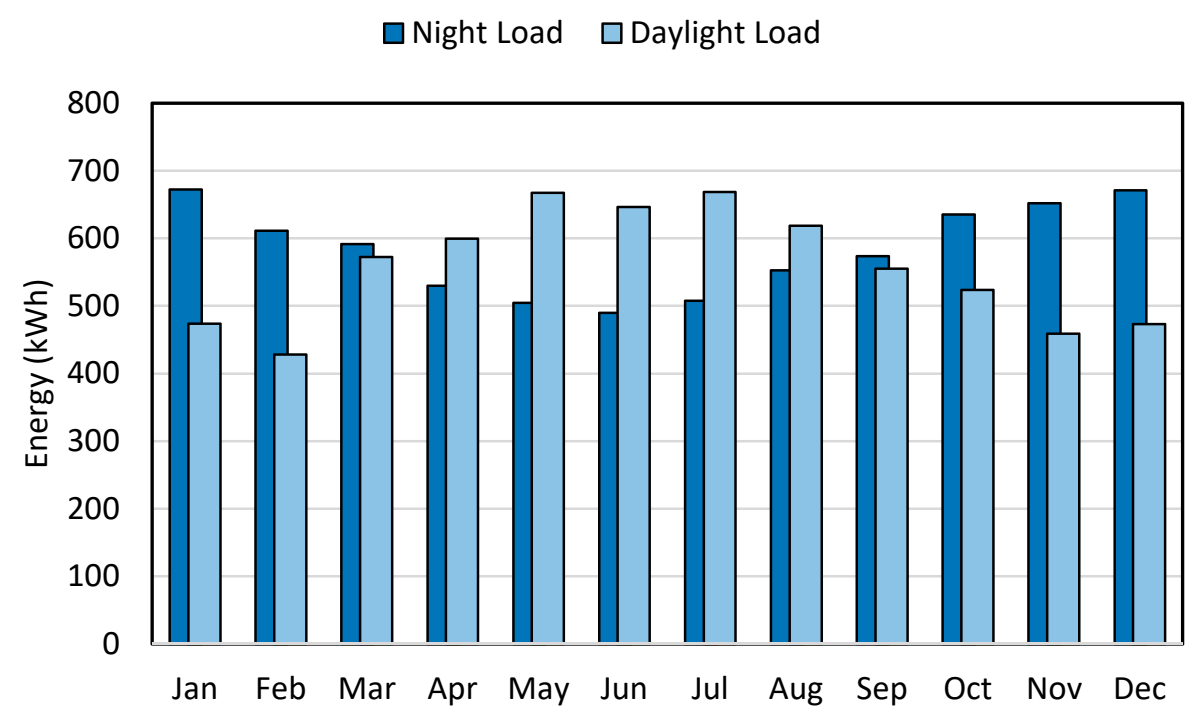

Figure 5. Load monthly electrical demand.

\section{Simulation Results}

Figure 6 shows that the monthly energy production from the PV generator is shared among other sections of the plant (electrolyser, battery, grid and load) for the two considered load configurations, namely: Night Load and Daylight Load.

It can be noted that, for the daylight load configuration, a quota variable from $46 \%$ to $53 \%$ is directly delivered to the load; obviously, this cannot be the case of the night load configuration, when more than $90 \%$ of the produced energy is delivered to the electrolyser to be converted into hydrogen, while the remaining $10 \%$ is used for charging batteries.

As regards the energy delivered to the grid, it resulted equal to zero for the night load configuration and barely appreciable during August and September for daylight load configuration.

As far as the load is concerned, it is fed by either of the set of energy supplying sections of the plant (PV generator, battery, fuel cell, or the grid), as shown in Figure 7.

It is worth noting that, for the night load configuration, the fuel cell is able to satisfy a share of the energy demand which varies from about $30 \%$, occurring in the winter months (specifically, January, November, and December), to the $80 \%$ occurring in July. However, from March to September, more than $50 \%$ of the load demand is satisfied by the energy flux delivered by the fuel cell. Obviously, the residual load demand is met mainly by the grid and quite negligibly (with a monthly share of about $6 \%$ ) by the battery, which predominantly intervenes during the period beginning around or 
after sunset and lasting at most until midnight. This behavior is justified by the relatively low nominal capacity of the battery.

On the contrary, for the daylight load configuration, the fuel cell is only able to cover a percentage of energy demand which varies from $13 \%$ in December to $23 \%$ in July. In this case, the great part of the load is fed directly by the PV generator for a share which keeps it higher than $60 \%$ during the whole year. The grid residually intervenes, contributing only with a maximum share of about $20 \%$ in January and December, and an average value of about 3\% for the remaining part of the year. In addition, no appreciable contribution from the grid is present from July to September.

The grid contribution to the load demand is better inferable from the graph reported in Figure 8, where the energy amounts monthly delivered from the grid to the load in the two configurations are directly compared. It is clearly shown that, with the daylight load configuration, the contribution of the grid is remarkably lower.

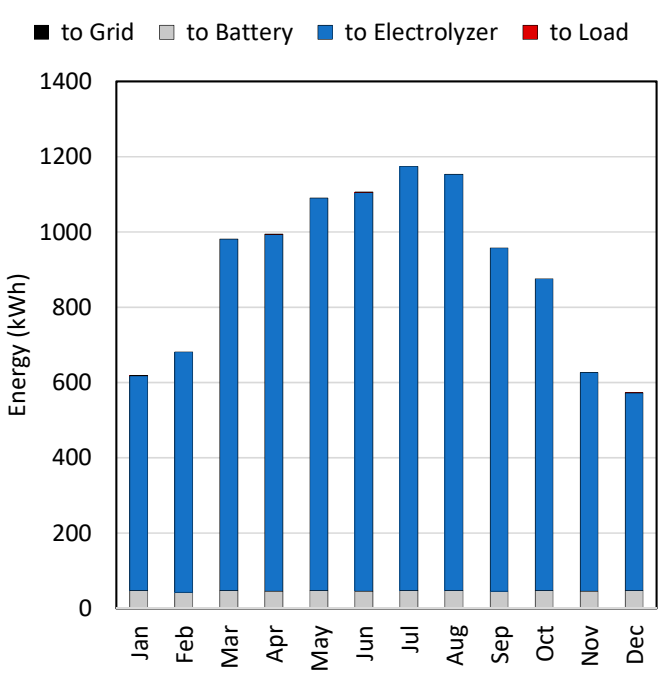

(a)

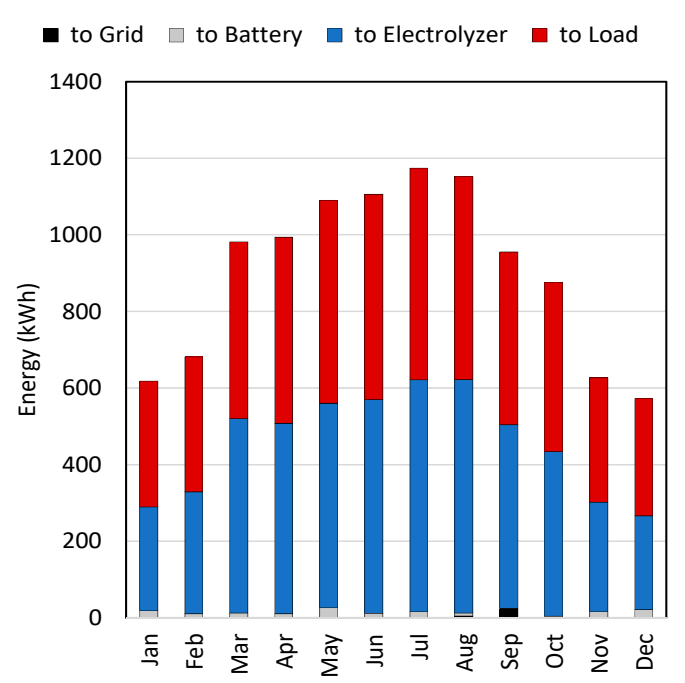

(b)

Figure 6. Uses of the energy production from PV, under two different load configurations: (a) Night load configuration; (b) Daylight load configuration.

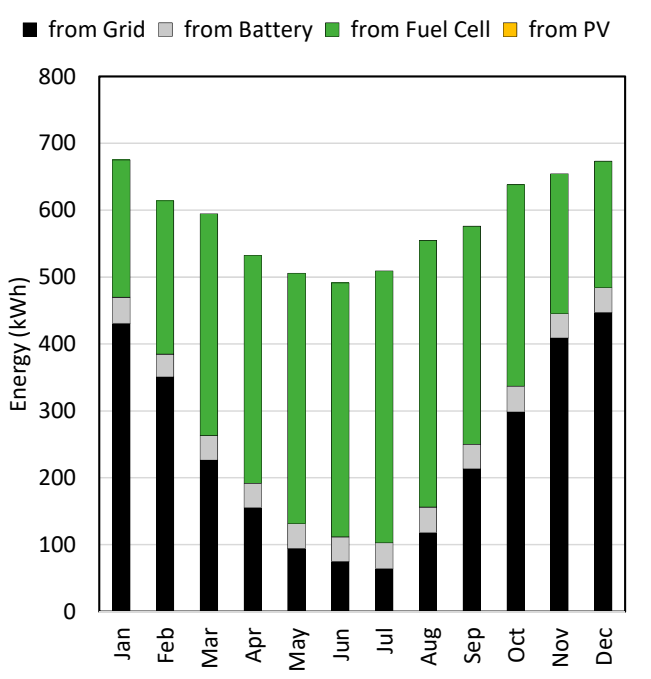

(a)

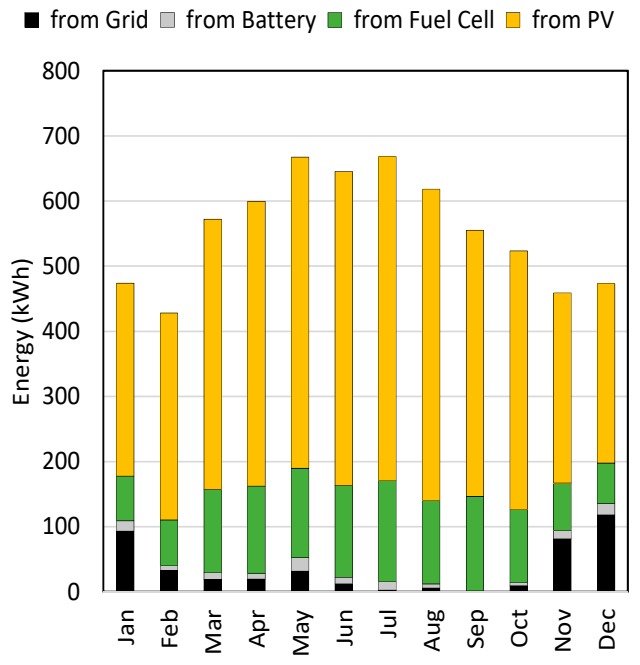

(b)

Figure 7. Share of energy sources feeding the load, under two different load configurations: (a) Night load configuration; (b) Daylight load configuration. 


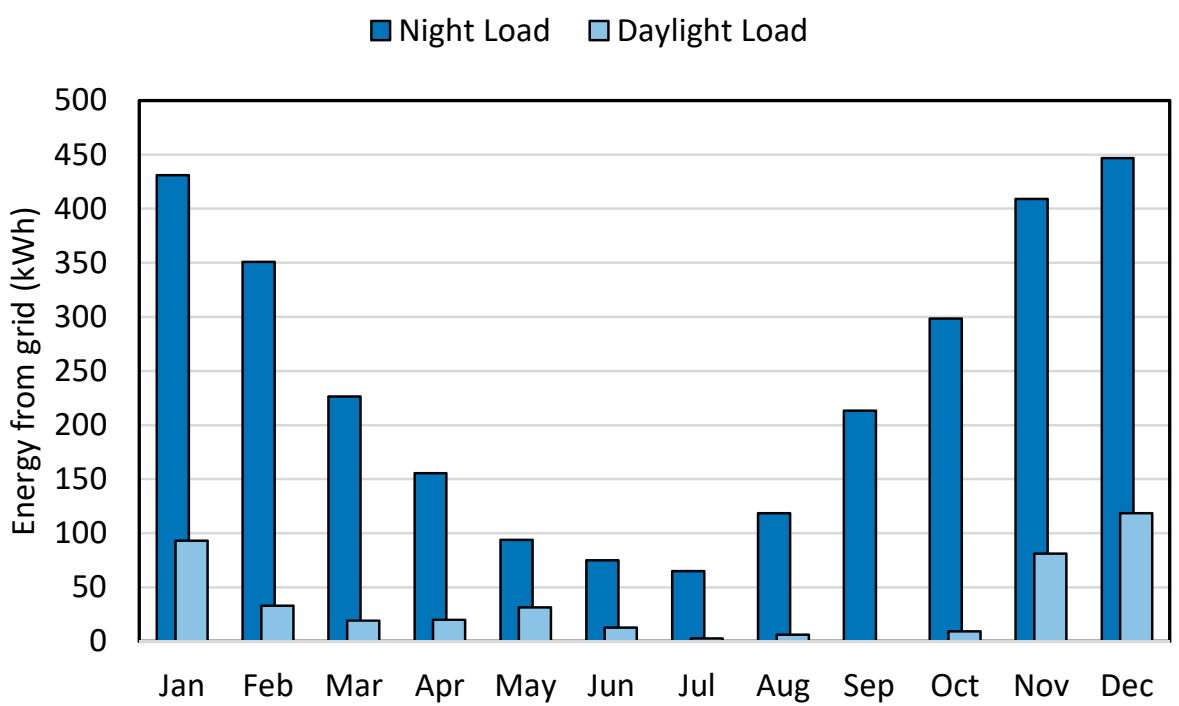

Figure 8. Grid contribution to the load demand, for two different load configurations.

These behaviors clearly reverberate on the hydrogen production from the PV system (Figure 9). As a matter of fact, with the night load configuration, all the PV energy production is able to be delivered to the electrolyser to be converted into hydrogen. Therefore, the hydrogen production is higher than the one obtainable with the daylight load configuration, with a maximum difference of about $15 \mathrm{~kg} / \mathrm{month}$ in both July and August.

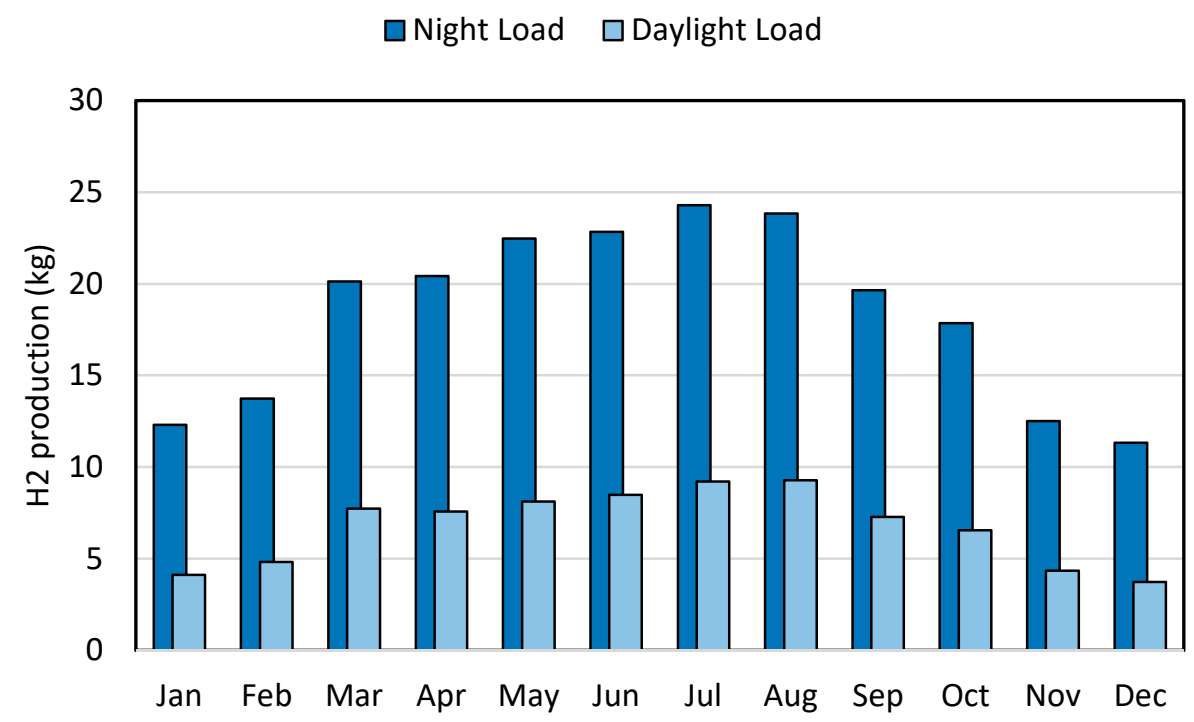

Figure 9. Monthly Hydrogen production, for two different load configurations.

Notwithstanding the quantity of hydrogen produced, it is worth noting that, with the night load configuration, the amount of gas which is able to be stored daily during the year (Figure 10) is reduced in comparison to the case of daylight load.

This is due to the fact that night load is prevalently satisfied by the fuel cell, which consumes the great part of the hydrogen produced by the electrolyser.

As a consequence, the tank remains quite empty for more than $40 \%$ of the year with the night load configuration and, moreover, the level never reaches the maximum point (corresponding to $1.8 \mathrm{~kg}$ of stored gas). These conclusions can be drawn from the graph in Figure 11, which depicts the percentage of time (frequency) with which the level of hydrogen reported on the x-axis persists within the tank. 


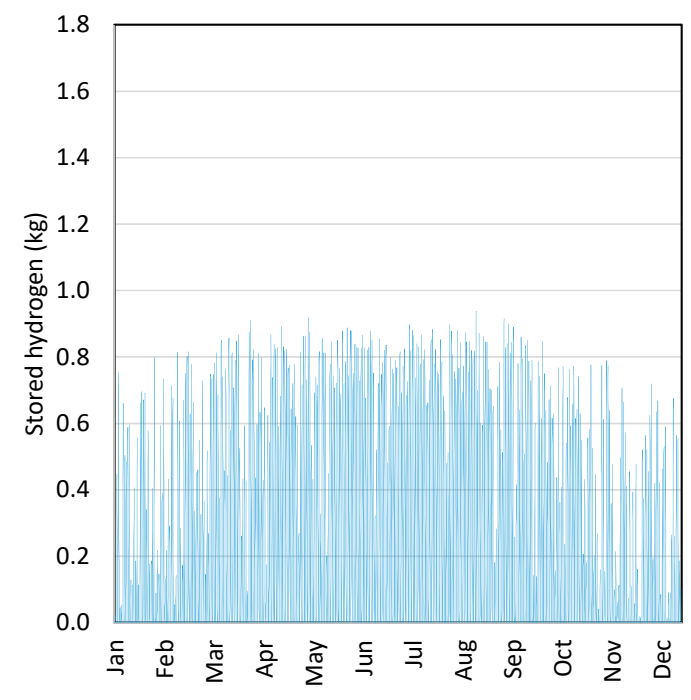

(a)

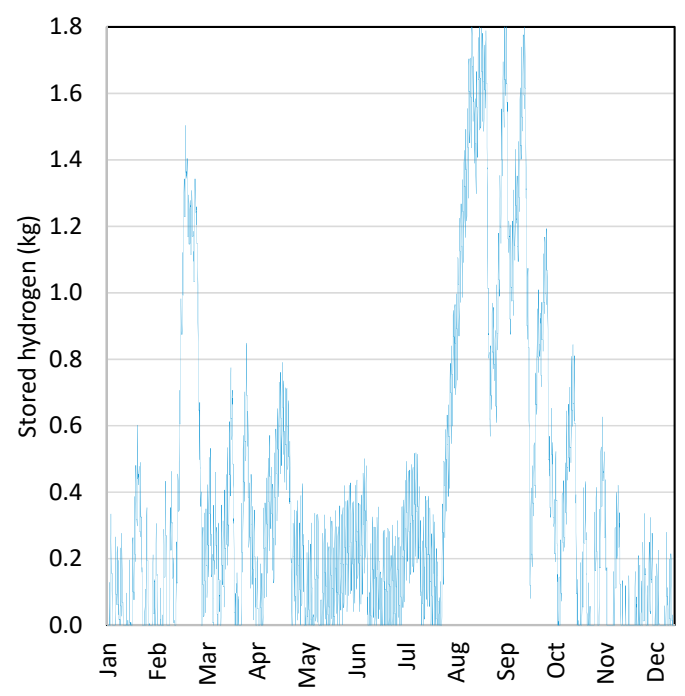

(b)

Figure 10. Stored hydrogen, for two different load configurations: (a) Night load configuration; (b) Day load configuration.

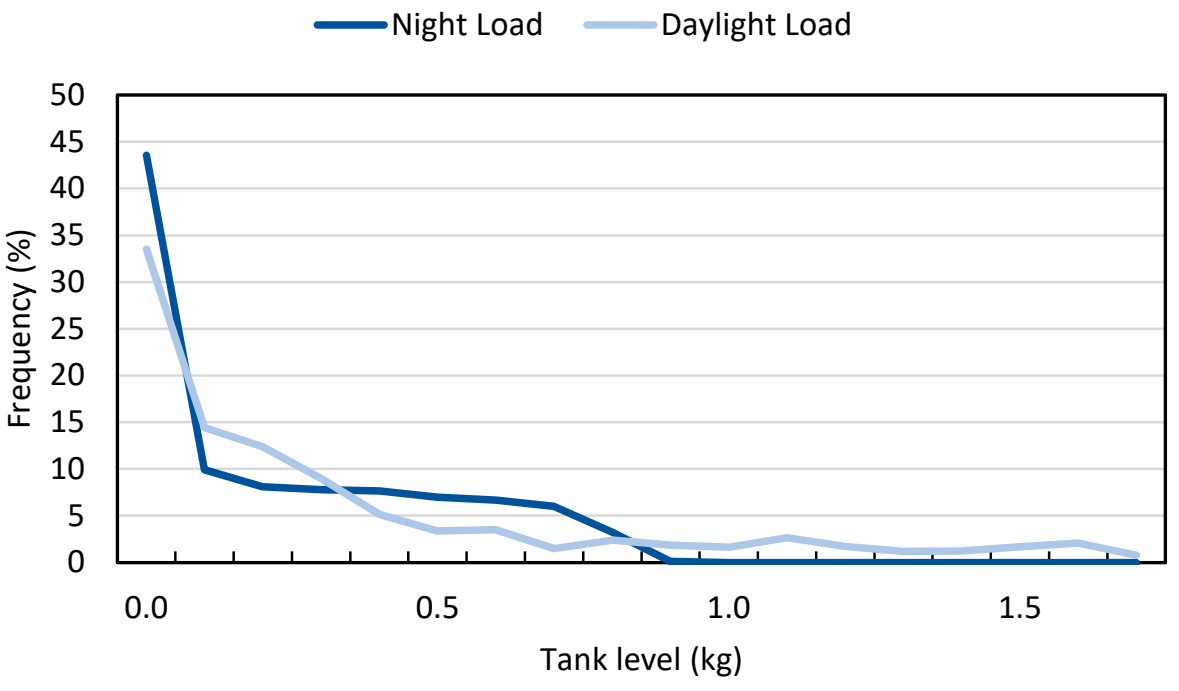

Figure 11. Tank level, for two different load configurations.

\section{Discussion}

Simulation results demonstrated that load configuration plays a pivotal role in the system operation: indeed, the mere change in the load activation period caused completely different system performances.

Obviously, the hydrogen production is maximized in the night load configuration, when all the PV generation can be used for this purpose. However, notwithstanding the major production, the available amount of hydrogen does not suffice to satisfy the load needs and the recourse to the grid delivered energy is appreciable.

On the contrary, if the load demand is confined to the daylight period, the PV generator can contribute to satisfy its energy demand, but, consequently, the hydrogen production is reduced. However, it is still sufficient to support the load need. As a consequence, in this case, the recourse to the grid-delivered energy is further reduced, and in summer the system is completely self-sufficient.

In any case, it is also worth noting that, in both configurations, the contribution of the renewable energy share is quite remarkable. This occurrence is inferable from the information reported in Figure 12, referring to the energy annually delivered from the various possible sources of the system. 
It is shown that, although the PV array production is obviously the same for both of the two examined cases, in the night load configuration, the electric energy annually produced by the fuel cell is more than twice the one obtained with the daylight load configuration, and so are the grid purchases, which are always the smallest amount among the three possible sources.

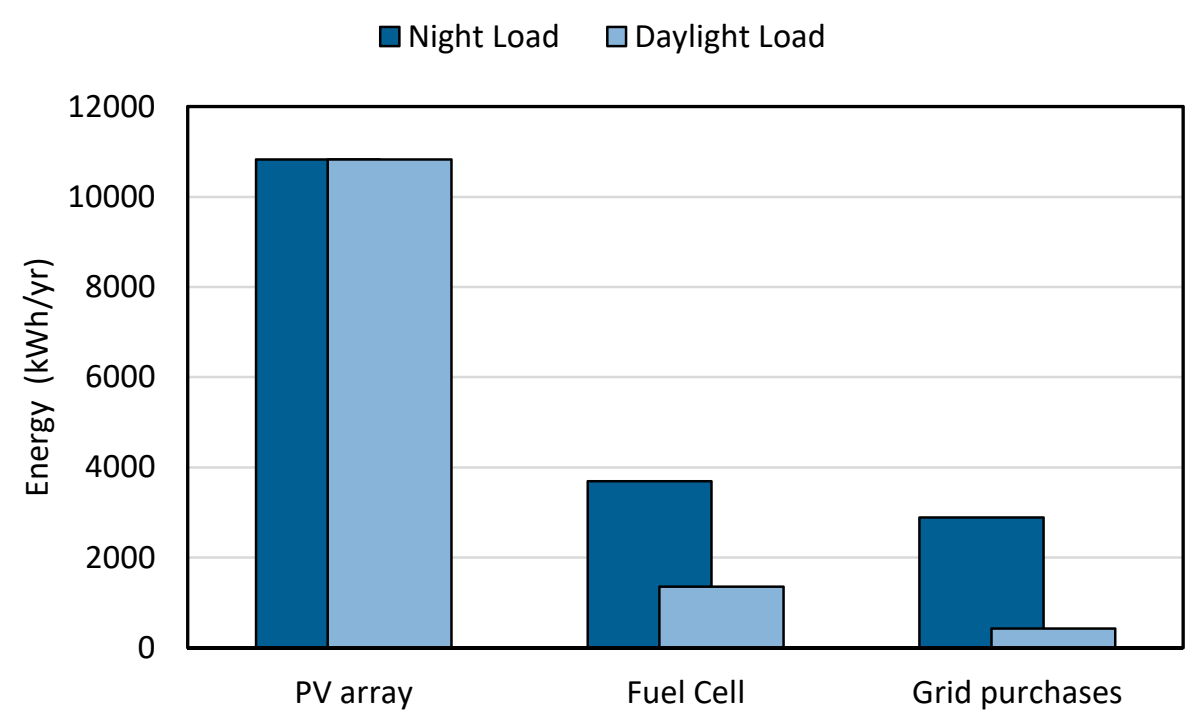

Figure 12. Energy annually provided by the various possible sources of the system.

As a result, the share of grid purchases is $17 \%$ for the night load configuration and only $3 \%$ for the daylight load configuration.

As regards the renewable energy contribution, it may be expressed in terms of renewable fraction, $f_{R}$, namely, the ratio of the yearly renewable energy production to the total yearly involved energy, including the annual grid purchases, i.e.:

$$
f_{R}=\frac{E_{P V}+E_{F C}}{E_{P V}+E_{F C}+E_{G P}}
$$

where:

$E_{P V}$ is the annual PV array production $(\mathrm{kWh} / \mathrm{yr}) ;$

$E_{F C}$ is the annual electric energy produced by the Fuel Cell (kWh/yr);

$E_{G P}$ is the annual electric energy purchased from the grid $(\mathrm{kWh} / \mathrm{yr})$.

In all the examined cases, the renewable fraction is always higher than $80 \%$. Specifically, it is $83 \%$ for the night load configuration and $97 \%$ for the daylight load configuration.

As far as the hydrogen production is concerned, it is worth noting that rarely is the tank capacity saturated. This occurrence only happens during summer in case of daylight load configuration.

In order to entirely exploit the tank capacity, the hydrogen production might be further improved by enhancing either the electrolyser potentiality or the PV panel surface (or both).

Given that the electrolyser can work with a maximum feeding power of $10 \mathrm{~kW}$, there is still space for enhancing the panel surface (currently corresponding to a peak power of $6 \mathrm{kWp}$ ), so that the electrolyser working conditions may be kept at a higher rate.

Obviously, increasing the hydrogen availability might enhance the fuel cell production and, hence, the renewable factor might be improved, especially in the case of night load configuration.

In this direction, future configuration of the system should evolve. 


\section{Conclusions}

The present work proposes and discusses the results of a series of simulations regarding the performances of a composite plant designed to use solar energy for the combined production of electricity and hydrogen; the gas is successively exploited to feed a fuel cell which, in turn, supplies an electrical load. Specifically, the system is a compound prototype, constituted of a RES unit, a hydrogen production section, a power section, and storage devices, designed to operate either in grid-connected or stand-alone mode, especially within energy networks exploiting distributed micro-generation schemes.

The load demand was hypothesized to be completely confined within the daylight period or, alternatively, within the nighttime; in both the examined cases, the load assumed a time-constant value of $1.5 \mathrm{~kW}$.

The aim was to investigate the influence of the load configuration on the performance of the whole system, so that information about future plant patterns and operation can be obtained, especially with regard to the features of the energy demand, which is able to be efficiently met by the system, possibly with a minimal involvement of the power grid.

Simulation results allowed interesting conclusions to be drawn.

- Firstly, in the current configuration, the share of renewable energy resulted greater than $80 \%$ in all the examined cases (it reaches $93 \%$ in case of daylight load configuration). This is an encouraging outcome in view of achieving a self-sufficient arrangement.

- Load configuration played a pivotal role in the system operation mode: the mere variation of the load activation period caused substantial difference in the modality with which the load demand is satisfied by the different energy sources constituting the system.

- The current configuration of the system seems to be suited to feed loads which persist prevalently during daytime, whereas to feed loads prevalently confined to nighttime, the production of hydrogen should be improved.

- There is space to improve the hydrogen production, since the hydrogen tank capacity is rarely saturated. Saturation only occurs in summer in the case of daylight load configuration. In order to fulfill the task, enlarging the PV array surface appears to be the best course of action, also considering its simpler technical feasibility.

- In this direction, the design of future development of the system structure should be oriented. However, it is worth noting that every definitive conclusion in this regard is to be supported by future experimental data, whose acquisition is the upcoming step of the current research activity.

As a matter of fact, the analysis here presented is to be considered as part of a broader research activity, which is aimed at the analysis of the system performances, also from an experimental point of view, in order to both verify the reliability of these types of apparatuses and of their components, at least in the Mediterranean climate, and prove the existence of possible optimal configurations in view of self-sufficient arrangements.

Author Contributions: The co-authors together equally contributed to the completion of this article. Conceptualization, R.C., C.M., A.N., and M.P.; Data curation, R.C., C.M., and M.F.P.; Methodology, R.C., C.M., A.N., M.F.P., and M.P.; Software, A.N. and M.F.P.; Supervision, M.P.

Funding: This work was carried out within the research project No. 201594LT3F, "La ricerca per i PAES: una piattaforma per le municipalità partecipanti al Patto dei Sindaci (Research for SEAP: a platform for municipalities taking part in the Covenant of Mayors)," which is funded by the PRIN (Programmi di Ricerca Scientifica di Rilevante Interesse Nazionale) of the Italian Ministry of Education, University and Research.

Conflicts of Interest: The authors declare no conflict of interest. 


\section{References}

1. Gössling, S. 7-Rights, Authority, and the Police. In The Psychology of the Car; Gössling, S., Ed.; Elsevier: Amsterdam, The Netherlands, 2017; pp. 139-169. ISBN 978-0-12-811008-9.

2. Hvelplund, F. Renewable energy and the need for local energy markets. Energy 2006, 31, $2293-2302$. [CrossRef]

3. Lund, H. The implementation of renewable energy systems. Lessons learned from the Danish case. Energy 2010, 35, 4003-4009. [CrossRef]

4. Foley, A.; Olabi, A.G. Renewable energy technology developments, trends and policy implications that can underpin the drive for global climate change. Renew. Sustain. Energy Rev. 2017, 68, 1112-1114. [CrossRef]

5. Narayanan, A.; Mets, K.; Strobbe, M.; Develder, C. Feasibility of $100 \%$ renewable energy-based electricity production for cities with storage and flexibility. Renew. Energy 2019, 134, 698-709. [CrossRef]

6. da Silva, C.G. Renewable energies: Choosing the best options. Energy 2010, 35, 3179-3193. [CrossRef]

7. European Parliament and the Council of the European Union. The promotion of the use of energy from renewable sources. Off. J. Eur. Union 2018, 61, 82-209.

8. Malara, A.; Marino, C.; Nucara, A.; Pietrafesa, M.; Scopelliti, F.; Streva, G. Energetic and economic analysis of shading effects on PV panels energy production. Int. J. Heat Technol. 2016, 34, 465-472. [CrossRef]

9. Gelazanskas, L.; Gamage, K.A.A. Demand side management in smart grid: A review and proposals for future direction. Sustain. Cities Soc. 2014, 11, 22-30. [CrossRef]

10. Siano, P. Demand response and smart grids-A survey. Renew. Sustain. Energy Rev. 2014, 30, 461-478. [CrossRef]

11. Gattuso, D.; Greco, A.; Marino, C.; Nucara, A.; Pietrafesa, M.; Scopelliti, F. Sustainable mobility: Environmental and economic analysis of a cable railway, powered by photovoltaic system. Int. J. Heat Technol. 2016, 34, 7-14. [CrossRef]

12. Briggs, I.; Murtagh, M.; Kee, R.; McCulloug, G.; Douglas, R. Sustainable non-automotive vehicles: The simulation challenges. Renew. Sustain. Energy Rev. 2017, 68, 840-851. [CrossRef]

13. Sinigaglia, T.; Lewiski, F.; Martins, M.E.S.; Siluk, J.C.M. Production, storage, fuel stations of hydrogen and its utilization in automotive applications-A review. Int. J. Hydrogen Energy 2017, 42, 24597-24611. [CrossRef]

14. International Energy Agency. Transition to Sustainable Buildings; International Energy Agency: Paris, France, 2013.

15. Energy Roadmap 2050; European Commission Communication from the Commission to the European Parliament, the Council, the European Economic and Social Committee and the Committee of the Regions: Brussels, Belgium, 2011.

16. Marszal, A.J.; Heiselberg, P.; Bourrelle, J.S.; Musall, E.; Voss, K.; Sartori, I.; Napolitano, A. Zero Energy Building-A review of definitions and calculation methodologies. Energy Build. 2011, 43, 971-979. [CrossRef]

17. Sartori, I.; Napolitano, A.; Voss, K. Net zero energy buildings: A consistent definition framework. Energy Build. 2012, 48, 220-232. [CrossRef]

18. Kolokotsa, D.; Rovas, D.; Kosmatopoulos, E.; Kalaitzakis, K. A roadmap towards intelligent net zero- and positive-energy buildings. Sol. Energy 2011, 85, 3067-3084. [CrossRef]

19. Marino, C.; Nucara, A.; Panzera, M.F.; Pietrafesa, M. Towards the nearly zero and the plus energy building: Primary energy balances and economic evaluations. Therm. Sci. Eng. Prog. 2019, 13, 100400. [CrossRef]

20. Mathiesen, B.V.; Duić, N.; Stadler, I.; Rizzo, G.; Guzović, Z. The interaction between intermittent renewable energy and the electricity, heating and transport sectors. Energy 2012, 48, 2-4. [CrossRef]

21. Krajačić, G.; Lončar, D.; Duić, N.; Zeljko, M.; Arántegui, R.L.; Loisel, R.; Raguzin, I. Analysis of financial mechanisms in support to new pumped hydropower storage projects in Croatia. Appl. Energy 2013, 101, 161-171. [CrossRef]

22. Foley, A.; Lobera, I.D. Impacts of compressed air energy storage plant on an electricity market with a large renewable energy portfolio. Energy 2013, 57, 85-94. [CrossRef]

23. López-Sabirón, A.M.; Royo, P.; Ferreira, V.J.; Aranda-Usón, A.; Ferreira, G. Carbon footprint of a thermal energy storage system using phase change materials for industrial energy recovery to reduce the fossil fuel consumption. Appl. Energy 2014, 135, 616-624. [CrossRef]

24. Carbone, R. PV plants with distributed MPPT founded on batteries. Sol. Energy 2015, 122, 910-923. [CrossRef] 
25. Ogawa, T.; Takeuchi, M.; Kajikawa, Y. Analysis of trends and emerging technologies in water electrolysis research based on a computational method: A comparison with fuel cell research. Sustainability 2018, 10, 478. [CrossRef]

26. Wulf, C.; Kaltschmitt, M. Hydrogen supply chains for mobility-Environmental and economic assessment. Sustainability 2018, 10, 1699. [CrossRef]

27. Saeedmanesh, A.; Mac Kinnon, M.A.; Brouwer, J. Hydrogen is essential for sustainability. Curr. Opin. Electrochem. 2018, 12, 166-181. [CrossRef]

28. Gómez-Camacho, C.E.; Ruggeri, B. Energy Sustainability Analysis (ESA) of Energy-Producing Processes: A Case Study on Distributed H2 Production. Sustainability 2019, 11, 4911. [CrossRef]

29. Carroquino, J.; Bernal-Agustín, J.L.; Dufo-López, R. Standalone Renewable Energy and Hydrogen in an Agricultural Context: A Demonstrative Case. Sustainability 2019, 11, 951. [CrossRef]

30. Raj, A.S.; Ghosh, P.C. Standalone PV-diesel system vs. PV-H2 system: An economic analysis. Energy 2012, 42, 270-280. [CrossRef]

31. Kang, L.; Jiang, Y.; Liu, Y. Impacts of synthesis schemes on economy and flexibility of hydrogen networks. Chem. Eng. Sci. 2019, 207, 1159-1174. [CrossRef]

32. Baghaee, H.R.; Mirsalim, M.; Gharehpetian, G.B.; Talebi, H.A. Reliability/cost-based multi-objective Pareto optimal design of stand-alone wind/PV/FC generation microgrid system. Energy 2016, 115, 1022-1041. [CrossRef]

33. Baghaee, H.R.; Mirsalim, M.; Gharehpetian, G.B.; Talebi, H.A. A Decentralized Power Management and Sliding Mode Control Strategy for Hybrid AC/DC Microgrids including Renewable Energy Resources. IEEE Trans. Ind. Inform. 2017, 1. [CrossRef]

34. Marino, C.; Nucara, A.; Pietrafesa, M. Electrolytic hydrogen production from renewable source, storage and reconversion in fuel cells: The system of the "Mediterranea" University of Reggio Calabria. Energy Procedia 2015, 78, 818-823. [CrossRef]

35. Marino, C.; Nucara, A.; Panzera, M.F.; Pietrafesa, M.; Varano, V. Energetic and economic analysis of a stand alone photovoltaic system with hydrogen storage. Renew. Energy 2019, 142, 316-329. [CrossRef]

36. HOMER. The Hybrid Optimization Model for Electric Renewables; Homer Energy, LLC: Boulder, CO, USA, 2015.

37. Kottek, M.; Grieser, J.; Beck, C.; Rudolf, B.; Rubel, F. World map of the Köppen-Geiger climate classification updated. Meteorol. Zeitschrift 2006, 15, 259-263. [CrossRef] 